J. Dairy Sci. 99:5345-5357

http://dx.doi.org/10.3168/jds.2015-10842

(C) American Dairy Science Association ${ }^{\circledR}, 2016$.

\title{
Prediction of rumen fiber pool in cattle from dietary, fecal, and animal variables
}

\author{
P. Huhtanen, ${ }^{* 1}$ E. Detmann, $†$ and S. J. Krizsan* \\ *Department of Agricultural Research for Northern Sweden, Swedish University of Agricultural Sciences, S-901 83 Umeå, Sweden \\ †Department of Animal Science, Federal University of Viçosa, Viçosa, Minas Gerais, Brazil, 36570-900
}

\begin{abstract}
Feed intake control in ruminants is based on the integration of physical constraints and metabolic feedbacks. Physical constraints are related to the fill caused by the weight or volume of digesta in the reticulo-rumen. The amount of neutral detergent fiber (NDF) in the rumen (RNDF) may be used as an indicator of rumen fill. The objective of this study was to develop equations predicting RNDF from diet and animal characteristics using a meta-analysis technique. A treatment mean data set (n $=314$ ) was obtained from 84 studies, in which rumen pool size and diet digestibility were determined in lactating cows $(\mathrm{n}=231)$ or growing cattle $(\mathrm{n}=83)$. The data were analyzed using linear and nonlinear mixed models. Intake, rumen pool size, and fecal output of $\mathrm{NDF}$ were scaled to body weight $(\mathrm{BW})^{1.0}$. Due to the heterogeneous nature of dietary NDF, predictions of RNDF based on NDF intake were not precise. Predictions were markedly improved by dividing NDF into potentially digestible and indigestible fractions, because rumen turnover time of indigestible NDF was 2.7 times longer than that of potentially digestible NDF. At equal NDF intake, RNDF was negatively associated with dietary crude protein concentration and positively with the proportion of concentrate in the diet. Models based on fecal NDF output generally performed better than those based on NDF intake, probably because the effects of intrinsic characteristics of dietary cell walls and associative effects of dietary components collectively influence fecal NDF output. The model based on fecal NDF output was improved by including dietary concentration of forage NDF in the model, reflecting slower turnover of forage NDF compared with concentrate NDF. The curvilinear relationship between fecal NDF output and RNDF could be described by a quadratic, Mitscherlich, or power function equation, which
\end{abstract}

Received December 31, 2015.

Accepted March 2, 2016.

${ }^{1}$ Corresponding author: pekka.huhtanen@slu.se performed better than the quadratic or Mitscherlich equation. In addition to fecal NDF output and dietary concentration of forage NDF, animal and forage type had significant effects on RNDF. At the same fecal NDF output, growing cattle had a smaller RNDF than dairy cattle. Increased proportion of alfalfa or corn silages in forage decreased RNDF and increased proportion of tropical forages decreased it. It is concluded that RNDF can be predicted precisely from intake or fecal output data, and that predicted RNDF can be a useful tool in understanding the interplay between physical and metabolic factors regulating feed intake in ruminants.

Key words: diet composition, fecal output, modeling, rumen fiber pool

\section{INTRODUCTION}

Accurate prediction of DMI is important for the formulation of economical dairy cow diets. Regulation of feed intake in ruminants involves multiple mechanisms related to dietary and animal factors that are poorly understood (Mertens, 1994a). Several empirical models predicting DMI in cattle have been developed over the past 30 to $40 \mathrm{yr}$, but no intake model can generally be used for different types of animals fed a wide range of diets. Limited success in this field is at least partly due to complicated interactions between the animal and feed characteristics, and difficulties in distinguishing and quantifying these factors. The main theory of intake control in ruminants is based on the integration of physical constraints and metabolic feedbacks, which in turn determines the maximum DMI for a specific animal under a particular feeding situation (Crampton, 1957; Blaxter et al., 1961; Conrad et al., 1964). Based on this concept, Mertens (1987, 1994a) developed the NDF-Energy intake system. This approach is based on a theoretical relationship between dietary NDF and energy (i.e., intake is limited by the energy demand of the animal or the physical fill of the diet). Maximum intake occurs at the intersection of those theories of intake regulation (Mertens, 1994a). 
Evaluation of intake data from feeding experiments in dairy cows does not provide support to the bi-phasic intake regulation theory because no set-point either for physical or for metabolic feedback mechanisms could be detected. Rumen pool size of NDF decreases with improved digestibility of grass silage (Bosch et al., 1992; Rinne et al., 2002), suggesting that cows do not use all the rumen capacity when highly digestible grass silages are fed. However, DMI increased with improved forage digestibility rejecting the hypothesis that intake was limited by energy intake. Similarly, with increased concentrate supplementation (Keady et al., 2004; Huhtanen et al., 2008), quadratic DMI responses do not support the bi-phasic intake regulation theory. Within physical limitation, the DMI should increase linearly with increased concentrate allowance due to the reduced NDF content (i.e., gut fill) of the diet. On the other hand, no break-point of DMI was reached even with the highest levels of concentrates. These observations support the integration of physical and metabolic constraints on ruminant intake. Fisher et al. (1987) proposed a model integrating the physical and metabolic constraints on ruminant feed intake. They presented a model with a double exponential term expressing intake as a function of rumen distension and nutrient flow, intending to relate the strength of each stimulus in relation to the other. Following this concept, Detmann et al. (2014) presented a model based on energy content and bulkiness of the diet. This model showed that DMI is simultaneously regulated by both physical constraints and metabolic feedbacks.

A better understanding of the additive nature of feedback mechanisms would lead to more accurate predictions of voluntary DMI (Allen, 1996). Progress made in the prediction of DMI by mechanistic models has been disappointing, primarily because of an inadequate understanding of the mechanisms that affect flow from the reticulorumen and insufficient data with which to develop and validate models (Allen, 1996). One difficulty in modeling the effects of physical limitation is how to express rumen capacity or filling (distension) effect of the feed or diet. It could be speculated that the size of rumen NDF pool is the best descriptor of rumen fill or capacity, because nonfiber DM can be assumed to occupy very little rumen capacity. The rumen evacuation technique has been used to determine NDF pool size and parameters related to fiber kinetics. However, this technique is invasive, time-consuming, expensive, and laborious, and demands rumen-cannulated animals. Therefore, our objective was to evaluate if rumen $\mathrm{NDF}$ pool can be predicted from feed intake, fecal output, and diet characteristics using a meta-analytical approach.

\section{MATERIALS AND METHODS}

\section{Experimental Data}

A treatment means data set $(\mathrm{n}=314)$ was obtained from 84 studies, in which rumen pool size and diet digestibility were determined either in lactating dairy cows $(n=231)$ or growing cattle $(n=83$; Supplemental File; http://dx.doi.org/10.3168/jds.2015-10842), and used for statistical analysis to predict rumen pool size of NDF (RNDF). Rumen pool size was determined by manual evacuation of rumen contents. Diet digestibility was determined using either total fecal collection or different external or internal markers. The minimum prerequisite for an experiment to be included in the data set was that BW, forage and total DMI, adequate diet characterization (forage plant species, forage and concentrate NDF concentrations, dietary CP concentration, RNDF, and total-tract NDF digestibility) were available. In addition, data on dietary concentrations of indigestible NDF (iNDF), rumen pool sizes of fresh matter, DM and OM, and total-tract OM digestibility were collected.

Forage species were classified as temperate grasses, tropical grasses, corn silage, whole crop (barley, wheat) silage, alfalfa, other legumes (mainly red clover), and straw. Proportions of each forage type of the total forage DMI were calculated. Proportions of concentrate of total intake were calculated on DM and NDF basis. Intake, rumen pool size, and fecal output of NDF $\{\mathrm{NDF}$ intake $\times 0.001 \times[1,000-$ NDF digestibility $(\mathrm{g} / \mathrm{kg})]\}$ were scaled to $\mathrm{BW}^{1.0}(\mathrm{~g} / \mathrm{kg}$ of $\mathrm{BW})$. Scaling to $\mathrm{BW}^{1.0}$ can be justified because fiber occupies space in the gastrointestinal tract and rumen pool size is likely to scale to BW $^{1.0}$ (Mertens, 1987; Van Soest, 1994).

\section{Statistical Analysis}

Deviating properties of RNDF were investigated from leverage and influence using the DFFITS Dand $_{i}$ DFBETAS $_{j i}$ diagnostics, where $i=1,2, \ldots, 318$ and $j, i$ denotes the $j$ th regression coefficient in the regression equation ( $=0$ or 1$)$ estimated without observation $i$, where $i=1,2,3 \ldots, 318$, respectively (Belsley et al., 1980). Cut-off values suggesting that an observation warrants further examination were set at $\left|\operatorname{DFFITS}_{i}\right|>$ $2 \sqrt{ }(\mathrm{p} / \mathrm{n})$ and $\mid$ DFBETAS $_{j, i} \mid>2 / \sqrt{ } \mathrm{n}$, where $\mathrm{p}$ is the number of parameters estimated in the model and $n$ is the total number of observations. After outliers were removed, the data set contained a total of 294 treatment mean observations (dairy cows 220 , growing cattle 74 ).

The relationships between RNDF (g/ $\mathrm{kg}$ of $\mathrm{BW}$ ) and independent variables were explored by regression 
analysis within the MIXED procedure of SAS 9.4 (Littell et al., 1996) using the following basic model:

$$
\begin{aligned}
Y_{i j}= & B_{0}+b_{o}+B_{1} \times X_{1 i j}+b_{1} \times X_{1 i j}+\ldots+B_{n} \\
& \times X_{n i j}+b_{n} \times X_{n i j}+e_{i j},
\end{aligned}
$$

where $Y_{i j}$ is the value for the dependent variable $Y$ observed at level of $\mathrm{j}$ of the independent variable $X$ in the study $i, B_{0}$ is the overall intercept (fixed effect), $b_{0}$ is the random effect of study $i$ on the intercept $(i=$ $1 \ldots 84), B_{1} \ldots B_{n}$ are the regression coefficients of $Y$ on $X_{1} \ldots X_{n}$ of $Y$ across all studies (fixed effects), $X_{1 i j} \ldots$ $X_{n i j}$ are the values $j$ of the continuous variable $X_{1 \ldots} X_{n}$ in study $i, b_{i}$ is the random effect of study $i$ on the regression coefficient of $Y$ on $X_{1}$ in study $i(i=1 \ldots 84)$, and $e_{i j}$ is the residual error, which is assumed to be normally distributed.

The model [1] included 2 random statements: a random intercept and slope of $\mathrm{X}_{1}$ with SUBJECT $=$ Study using the TYPE $=$ UN (unstructured) covariance structure for random statement and maximum likelihood method for estimation. Only one random independent variable was used to avoid over-parameterized models and improve convergence (St-Pierre, 2001). Root mean square errors were adjusted for random study effect. The models were evaluated on the basis of Akaike's information criterion with correction (AICC) and root mean square error (RMSE) adjusted to random study effect according to St-Pierre (2001).

The nonlinear models tested in this study were power equation and the Mitscherlich equations, whose basic models were

$$
Y_{i j}=a \times X_{i j}{ }^{c}+\varepsilon_{i j} \text { (power equation), }
$$

where $a$ is a coefficient, $X_{i j}$ is intake or fecal output of $\mathrm{DM}$ or NDF, $c$ is the exponent and $\varepsilon_{i j}$ is the random error, which is assumed to have an asymptotic normal distribution; and

$$
Y_{i j}=A+B \times\left(1-e^{c \times X_{i j}}\right)+\varepsilon_{i j} \text { (Mitscherlich equation), }
$$

where $A$ is the intercept, $B$ is the potential increase to achieve the asymptotic value for rumen NDF pool $(A$ $+B), e$ is the Napier's number, $X_{i j}$ is the intake or fecal output of NDF, $c$ is the exponent, and $\varepsilon_{i j}$ is the random error, which is assumed to have an asymptotic normal distribution.

Because the RNDF can depend on other dietary and animal factors in addition to intake or fecal output of
NDF, both equation were extended to include these factors. Therefore, the power function may be expanded as follows:

$$
\begin{aligned}
Y_{i j} & =\left(b_{0} \times B+b_{1} \times X_{1}+b_{2} \times X_{2}+b_{3} \times X_{3}\right)^{\left(c_{0}+c_{1} \times X_{4}\right)} \\
& +\varepsilon_{i j},
\end{aligned}
$$

where $B$ is the fecal output $(\mathrm{g} / \mathrm{kg}$ of $\mathrm{BW}), X_{1} \ldots X_{4}$ are continuous variables, $b_{0} \ldots b_{3}$ are coefficients for the constant part of the equation, $c_{0}$ and $c_{1}$ are coefficients of the exponent part of the equation, and $\varepsilon_{i j}$ is the random error, which is assumed to have an asymptotic normal distribution. It is noticed that coefficients $b_{0}$ and $c_{0}$ encompasses the random variation among studies.

Similarly, the Mitscherlich model may be expanded as follows:

$$
Y_{i j}=A+B \times\left(1-e^{\left(c_{1} \times X_{1 i j}+\ldots+c_{n} \times X_{n i j}\right.}\right)+\varepsilon_{i j}
$$

where $A, B$, and $e$ were previously defined for model [3], and $c_{1} \ldots c_{n}$ are coefficients of variables $X_{1} \ldots X_{n}$. Variables $X_{1} \ldots X_{n}$ were previously selected based on linear model adjustments.

The NLMIXED procedure of SAS 9.4 (SAS Institute Inc., Cary, NC) was used to fit parameter values to data using study as the random effects (Littell et al., 1996). Parameter values were estimated using TRUREG optimization algorithm. A comparison of observed and predicted values was made using observations that were adjusted to account for the random study effect according to St-Pierre (2001).

\section{RESULTS}

\section{Data}

Chemical composition and feed intake are presented in Table 1. Diet parameters and feed intake exhibited considerable variation and covered ranges of relevance to commercial milk and beef production systems. On average, dietary concentration of $\mathrm{CP}$ was higher (168 vs. $129 \mathrm{~g} / \mathrm{kg}$ of DM) and that of NDF lower (383 vs. $491 \mathrm{~g} / \mathrm{kg}$ of DM) for dairy cows compared with growing cattle. Both average DMI (31 vs. $18 \mathrm{~g} / \mathrm{kg}$ of BW) and NDF intake (11.4 vs. 8.7$)$ were greater for dairy cows than for growing cattle.

Animal variables displayed wide ranges (Table 2), reflecting differences in BW, feed intake, and diet composition. Average digestibility of OM was higher in dairy cows than in growing cattle (710 vs. $680 \mathrm{~g} / \mathrm{kg}$ ). 
HUHTANEN ET AL.

Table 1. Descriptive statistics for the chemical composition of diets and voluntary feed intake

\begin{tabular}{|c|c|c|c|c|c|}
\hline Item & $\mathrm{n}$ & Mean & $\mathrm{SD}$ & Minimum & Maximum \\
\hline \multicolumn{6}{|c|}{ Diet composition (g/kg of DM) } \\
\hline $\mathrm{CP}$ & 294 & 158 & 37.4 & 46 & 269 \\
\hline NDF & 294 & 410 & 127.5 & 204 & 817 \\
\hline $\mathrm{iNDF}^{1}$ & 210 & 112 & 78.8 & 24 & 436 \\
\hline iNDF:NDF & 210 & 277 & 141.3 & 69 & 721 \\
\hline \multicolumn{6}{|l|}{ Intake $(\mathrm{kg} / \mathrm{d})$} \\
\hline Forage DM & 294 & 9.4 & 3.81 & 0.7 & 19.2 \\
\hline Concentrate DM & 294 & 6.0 & 4.21 & 0.0 & 15.5 \\
\hline Total DM & 294 & 15.4 & 6.47 & 2.9 & 28.6 \\
\hline $\mathrm{CP}$ & 294 & 2.56 & 1.38 & 0.2 & 5.8 \\
\hline $\mathrm{NDF}$ & 294 & 5.84 & 2.07 & 0.7 & 11.3 \\
\hline iNDF & 204 & 1.54 & 0.91 & 0.2 & 5.2 \\
\hline Concentrate $(\mathrm{g} / \mathrm{kg})$ & 294 & 357 & 201 & 0 & 800 \\
\hline \multicolumn{6}{|l|}{ Intake $(\mathrm{g} / \mathrm{kg}$ of $\mathrm{BW})$} \\
\hline $\mathrm{DM}$ & 294 & 27.5 & 7.94 & 8.4 & 50.6 \\
\hline NDF & 294 & 10.7 & 2.89 & 3.8 & 18.0 \\
\hline
\end{tabular}

${ }_{1 \mathrm{NDF}}=$ indigestible NDF.

Similarly, RNDF (10.5 vs. $8.8 \mathrm{~g} / \mathrm{kg}$ of BW) and fecal NDF output (4.7 vs. $3.4 \mathrm{~g} / \mathrm{kg}$ of BW) were greater in dairy cows than in growing cattle, respectively.

\section{Linear Models}

Rumen NDF pool scaled to BW $\mathrm{BW}^{0.92 \pm 0.044}$ when the data were adjusted for NDF intake $(\mathrm{g} / \mathrm{kg}$ of $\mathrm{BW})$, dietary concentration of iNDF, and animal type. The $95 \%$ asymptotic confidence interval (ACI) for the exponent was $\mathrm{ACI}_{0.95}:[0.83 \leq \beta \leq 1.01]$. The inclusion of parametric value 1 within ACI corroborates our previous assumption. Therefore, one can infer that rumen NDF pool can be described by scaling to $\mathrm{BW}^{1.0}$, which was then taken into account in the further analysis.

Intake of NDF (g/ $\mathrm{kg}$ of $\mathrm{BW}$ ) intake was positively $(P<0.001)$ associated with RNDF, whereas DMI was only weakly $(P=0.09)$ related to RNDF (model not shown; Table 3 ). The models presented in Table 3 were all derived from studies in which iNDF was determined.
However, model parameters were similar (intercept 3.9 vs. 3.7; slope 0.59 vs. 0.58 , respectively, for the whole data set $(\mathrm{n}=294)$ and iNDF data set $(\mathrm{n}=210)$. When no-intercept linear model was fitted, the slope of NDF intake increased to $0.94 \pm 0.023$. The model was slightly improved when NDF intake was separated into forage and concentrate NDF. The coefficient was greater $(0.62$ vs. $0.42 ; P=0.02)$ for forage NDF than for concentrate NDF. With the no-intercept model, the coefficients were 1.00 versus 0.62 for forage and concentrate NDF, respectively. Negative quadratic effect of NDF intake (NDFI) on RNDF was weak $(P=0.12)$. Prediction was clearly improved when NDFI was separated into iNDF and potentially digestible NDF (pdNDF) with the effect being 2.7 times greater for iNDF than for pdNDF on RNDF. When a no-intercept model was fitted, the coefficients were 1.67 and 0.61 for iNDF and pdNDF, respectively. According to AICC, the bivariate model based on NDF intake and iNDF concentration was marginally better than the corresponding models

Table 2. Descriptive statistics for BW, rumen pool size, and diet digestibility

\begin{tabular}{lccccc}
\hline Item & $\mathrm{n}$ & Mean & $\mathrm{SD}$ & Minimum & Maximum \\
\hline BW (kg) & 294 & 539 & 127.2 & 142 & 710 \\
Rumen pools (kg) & & & & & \\
Fresh & 233 & 76.9 & 19.7 & 19.0 & 117 \\
DM & 272 & 9.35 & 3.162 & 2.01 & 16.70 \\
OM & 168 & 8.75 & 2.902 & 2.22 & 14.20 \\
NDF & 294 & 5.42 & 1.940 & 0.97 & 9.33 \\
iNDF & 196 & 2.47 & 1.329 & 0.25 & 6.60 \\
NDF pool (g/kg of BW) & 294 & 10.0 & 3.03 & 2.6 & 20.6 \\
Digestibility (g/kg) & & & & 274 & 864 \\
OM & 281 & 703 & 87.2 & 195 & 890 \\
NDF & 294 & 592 & 129.2 & 0.25 & 5.88 \\
Fecal NDF (kg/d) & 294 & 2.40 & 1.141 & 0.7 & 10.4 \\
Fecal NDF (g/kg of BW) & 294 & 4.4 & 1.81 & & \\
\hline
\end{tabular}

${ }^{1} \mathrm{NDF}=$ indigestible $\mathrm{NDF}$. 
based on NDF intake and iNDF intake or iNDF:NDF ratio. Dietary CP concentration had a negative effect $(P<0.001)$ and proportion of concentrate in the diets (CProp) had a positive effect $(P=0.03)$ on RNDF when included as a third variable in the model. The effect of animal type (dairy vs. beef) was significant ( $P$ $<0.01$ ) when it was used as a dummy variable.

Equations predicting rumen pool size of iNDF and pdNDF from the intake of these components is shown in Table 4 . Intercepts of the regressions were positive for both iNDF $(P=0.003)$ and pdNDF $(P=0.026)$.

Fecal NDF output (FNDF, g/kg of BW) resulted in a better fit of model compared NDF intake in terms of smaller AICC (933 vs. 1024) and adjusted RMSE (0.59 vs. 0.68$)$ when analyzed with univariate regression models $(\mathrm{n}=294)$. The models presented in Table 5 are based on the whole data set $(\mathrm{n}=294)$ and therefore values AICC and adjusted RMSE are not directly comparable to intake models $(\mathrm{n}=210)$. Quadratic effect of FNDF was significant $(P<0.001)$ with predicted maximum RNDF values at $9.4 \mathrm{~g} / \mathrm{kg}$ of $\mathrm{BW}$ of FNDF. With regard to dietary variables, total and forage NDF concentration $(\mathrm{g} / \mathrm{kg}$ of diet $\mathrm{DM})$ resulted in the greatest improvement of the model when included in the quadratic FNDF model. Increased proportion of concentrate in the diet and dietary CP concentration decreased RNDF. The effect of dietary iNDF was not significant $(P=0.33)$ when included in the quadratic model of FNDF (model not shown). When the proportion of individual forages were included in the 3 -variable model (linear and quadratic effect of FNDF, and dietary NDF concentration), the coefficients were numerically positive for straw (0.56), whole-crop silages (0.58), and tropical grasses (0.98) and negative for corn silage $(-0.64)$ and alfalfa silage $(-0.74)$, whereas the coefficients for temperate grasses and legumes (excluding alfalfa) were close to zero. When the forages with positive and negative coefficients were combined into 2 groups (F-group A and F-group B, respectively), the fit of model was improved in terms of AICC (884 vs. 901; Table 5). The effects of both forage groups were significant. This model predicted a smaller $(P=0.01)$ RNDF for growing cattle compared with dairy cows (Table 6). Overall, for the data set with iNDF values (n $=210$ ), the models based on FNDF performed better than those based on NDF intake (AICC: 638 vs. 661; adjusted RMSE 0.53 vs. 0.55 , respectively; model not shown).

\section{Nonlinear Models}

The following power function and Mitscherlich equations were derived from NDF intake $(\mathrm{g} / \mathrm{kg}$ of $\mathrm{BW})$ :

$$
\begin{gathered}
\mathrm{RNDF}(\mathrm{g} / \mathrm{kg} \text { of } \mathrm{BW})=2.51 \pm 0.27 \\
\times \mathrm{NDFI}^{0.59 \pm 0.046}(\mathrm{AICC}=1,037), \quad[6] \\
\mathrm{RNDF}(\mathrm{g} / \mathrm{kg} \text { of } \mathrm{BW})=16.1 \pm 1.41 \\
\times\left(1-e^{-0.094 \pm 0.0136 \times \mathrm{NDFI}}\right)(\mathrm{AICC}=1,040), \quad[7] .
\end{gathered}
$$

It must be emphasized that when the corresponding models with intercept were fitted, AICC values did not decrease and the intercepts were nonsignificant.

According to AICC the best power function model performed better than Mitscherlich model (663 vs. 673) when animal type and diet characteristics were taken into account. At equal NDF intake, RNDF was smaller in growing cattle than in dairy cows (Table 7). Increasing proportion of corn and alfalfa silage in total forage intake decreased RNDF $(P=0.018)$. The increase in dietary concentration of iNDF was associated with an increased RNDF, whereas dietary $\mathrm{CP}$ concentration had a negative $(P=0.008)$ influence on RNDF.

In terms of AICC, the performance of the Mitscherlich model was improved when it was fitted using FNDF (g/ $\mathrm{kg}$ of BW) as an independent variable. The following simple Mitscherlich model was derived:

$$
\begin{gathered}
\mathrm{RNDF}(\mathrm{g} / \mathrm{kg} \text { of } \mathrm{BW})=13.6 \pm 0.52 \\
\times\left(1-e^{-0.35 \pm 0.026 \times \mathrm{FNDF}}\right)(\mathrm{AICC}=941) .
\end{gathered}
$$

The model was improved in terms of smaller AICC (895 vs. 941$)$ and residual variance (0.540 vs. 0.593$)$ when additional variables were included both to the constant (asymptotic value) and exponent (Table 8). Asymptotic value tended to be smaller $(P=0.09)$ for growing cattle than for dairy cows. It decreased $(P<0.001)$ with increased proportion of F-group A (corn silage + alfalfa) and increased $(P<0.001)$ when proportion of F-group B (tropical grass + whole-crop silage + straw) of total forage DM increased. Negative coefficients in the exponent part of equation indicate that RNDF increased as FNDF and proportion of forage NDF of total NDF increased. The effects of dietary concentrations of iNDF and CP were not significant when included in the model. Intercept was not significant and therefore was not included in the models.

When a simple power function based on FNDF $(\mathrm{g} / \mathrm{kg}$ of $\mathrm{BW}$ ) was adjusted, it fit to the data better than the simple Mitscherlich model:

$$
\begin{gathered}
\mathrm{RNDF}(\mathrm{g} / \mathrm{kg} \text { of BW})=5.04 \pm 0.21 \\
\times \mathrm{FNDF}^{0.48 \pm 0.025}(\mathrm{AICC}=921.9) .
\end{gathered}
$$


HUHTANEN ET AL.

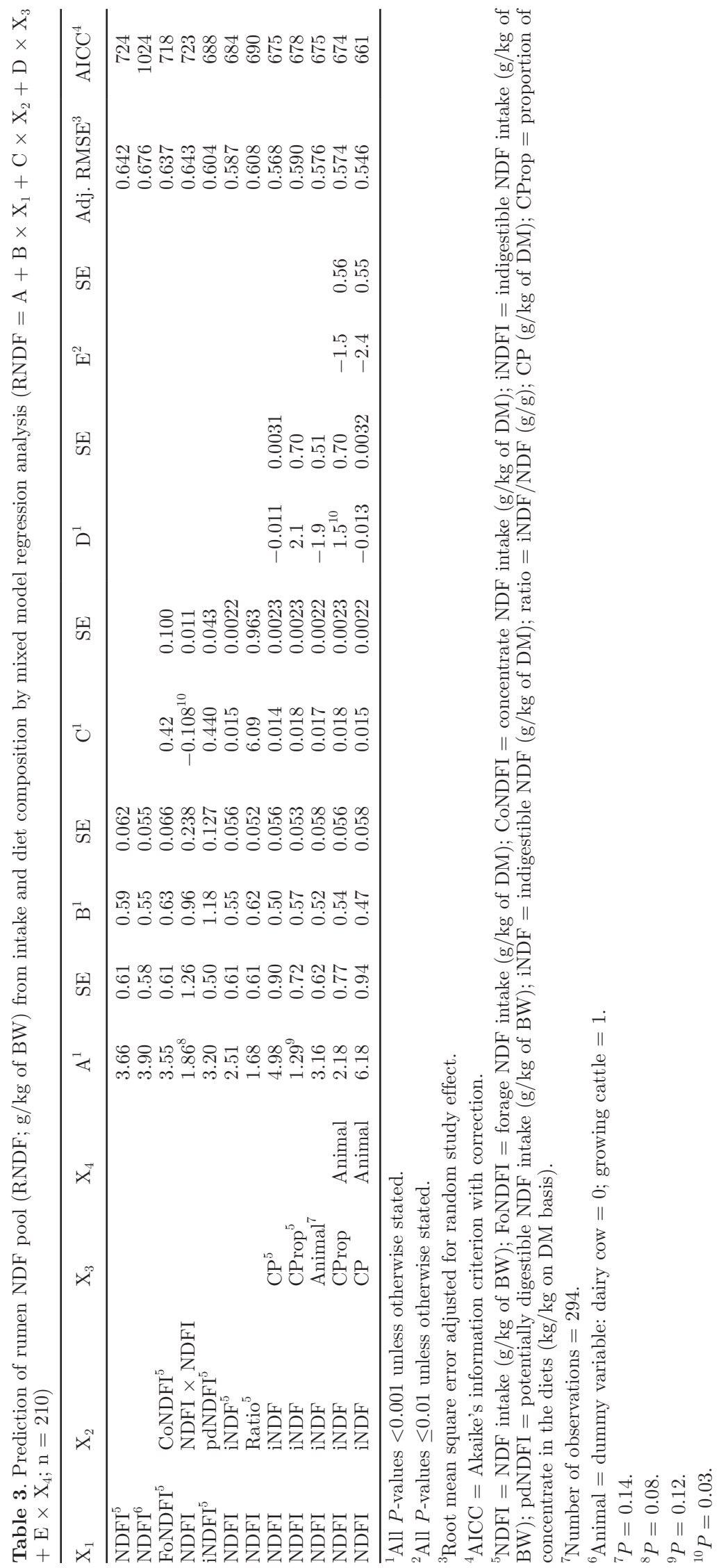


Table 4. Prediction of rumen pool (g/kg of BW) of indigestible NDF (iNDF) and potentially digestible NDF (pdNDF) from the intake of these components $(\mathrm{g} / \mathrm{kg}$ of $\mathrm{BW})$ by mixed model regression analysis $(\mathrm{Y}=\mathrm{A}+\mathrm{B} \times \mathrm{X}$ or $\mathrm{Y}=\mathrm{B} \times \mathrm{X} ; \mathrm{n}=210)$

\begin{tabular}{lccccccrr}
\hline $\mathrm{X}$ & $\mathrm{A}$ & $\mathrm{SE}$ & $P$-value & $\mathrm{B}$ & $\mathrm{SE}$ & $P$-value & Adj. RMSE $^{1}$ & AICC $^{2}$ \\
\hline iNDF pool & & & & & & & & \\
iNDFBW & & 0.63 & 0.202 & 0.003 & 1.40 & 0.088 & $<0.001$ & 0.450 \\
iNDFBW & & & 1.61 & 0.054 & $<0.001$ & 0.429 \\
$\begin{array}{l}\text { pdNDF pool } \\
\text { pdNDFBW }\end{array}$ & 1.11 & 0.487 & 0.026 & 0.54 & 0.073 & $<0.001$ & 471 \\
pdNDFBW & & & & 0.69 & 0.029 & $<0.001$ & 0.451 \\
\hline
\end{tabular}

${ }^{1} \mathrm{RMSE}$ adjusted for random study effect.

${ }^{2} \mathrm{AICC}=$ Akaike's information criterion with correction

${ }^{3}$ iNDFBW $=$ intake of iNDF $(\mathrm{g} / \mathrm{kg}$ of BW $)$.

${ }^{4} \mathrm{pdNDFBW}=$ intake of $\mathrm{pdNDF}(\mathrm{g} / \mathrm{kg}$ of $\mathrm{BW})$.

The best power function model (Table 9) had a lower AICC (871 vs. 895) and residual variance (0.472 vs. $0.540)$ than the best Mitscherlich model (Table 8). The constant of equation was smaller $(P=0.006)$ for growing cattle compared with dairy cows. Forage group A forages were associated with a smaller $(P<0.001)$ and F-Group B forages with a greater $(P=0.006)$ constant. Exponent increased $(P<0.001)$ with fecal NDF output and concentration of forage NDF in the diet, but it was not influenced $(P>0.10)$ by other dietary factors. Intercept was not significant and therefore was not included in the models. The effect of BW was not significant when added either to the best Mitscherlich or power function model. For the data set with iNDF $(\mathrm{n}=210)$, the models based on fecal NDF output performed better than models based on NDF intake (e.g., AICC for best power function models 609 vs. 663, respectively; model not shown).

\section{DISCUSSION}

\section{Intake Models}

Equation predicting RNDF from the intake of corresponding fraction is equivalent to the equation generally used for the Lucas test on digestible nutrients (Van Soest et al., 1992). The steady-state pool size of component in reticulo-rumen can be considered uniform when the pool fits general equation (Van Soest et al., 1992): $\mathrm{Q}_{\mathrm{x}}=\mathrm{T}_{\mathrm{xf}} \times \mathrm{F}_{\mathrm{x}}+\mathrm{Q}_{\mathrm{xm}}$, in which $\mathrm{T}_{\mathrm{xf}}$ and $\mathrm{Q}_{\mathrm{xm}}$ are the slope and the intercept of an equation predicting rumen pool of component $\mathrm{X}\left(\mathrm{Q}_{\mathrm{x}}\right)$ from intake of component $\mathrm{X}\left(\mathrm{F}_{\mathrm{x}}\right)$. The slope of this equation may represent the turnover time and the intercept an entity that should be analog to the metabolic component in the Lucas equation. In this sense, because NDF fractions do not have metabolic component, the significant intercept for the total NDF (Table 3) indicates that RNDF is heterogeneous. Such heterogeneity is supported by the time-dependency of NDF residence in the rumen, as the RNDF is composed by NDF consumed at different sequential days (Van Soest, 1994), which will then present different stages of degradation. Moreover, heterogeneity of RNDF can be related to variation among forage sources (Vieira et al., 2012 ) and in particle size (forage vs. concentrate NDF), potential digestibility and in digestion rate of pdNDF, making NDF intake a rather poor predictor of RNDF. In the present study, the intercept was greater (3.66 vs. 2.81) than reported by Vieira et al. (2008). When the quadratic effect of NDFI was included in the model, the intercept reduced and was not significantly $(P=0.14)$ different from zero. A numerically positive intercept may indicate that at low levels of NDFI the animals try to maintain a minimum rumen fill. Methane production after $120 \mathrm{~h}$ of fasting (Yan et al., 1997) supports this suggestion.

Turnover time of forage NDF was longer than that of concentrate NDF (1.00 vs. $0.62 \mathrm{~d}$; turnover rate 0.043 vs. $0.067 / \mathrm{h}$ ) when bivariate model with no intercept was fitted. This difference can result from the smaller particle size and consequently shorter rumen residence time of concentrate particles (Colucci et al., 1990; Mambrini and Peyraud, 1997) or small fecal particles compared with large forage particles (Wylie et al., 2000). Cannas and Van Soest (2000) used experiments where both forage and concentrate passage rate was measured at the same time and found a slope of 1.57 when regressing concentrate passage rate on forage passage rate. Probability of particles to escape is inversely related to particle size (Poppi et al., 1980), and particles must be reduced to a specific size to become eligible for passage. Very slow passage rate $(<0.003-0.006 / \mathrm{h})$ of particles $>1.25 \mathrm{~mm}$ determined by rumen evacuation technique (Bayat et al., 2010) suggests that initial particle size of the diet and the rate of breakdown of large particles to small particles influences turnover time of NDF in the rumen.

Dividing NDF intake into iNDF and pdNDF or using dietary iNDF concentration either on DM or NDF basis improved prediction of RNDF considerably. Filling ef- 
fect of iNDF can be expected to be greater than that of pdNDF because iNDF can only be removed from the rumen by passage, whereas pdNDF disappears both by passage and digestion. Retention time is solely a function of passage only when the nutrient is indigestible, but turnover time of digestible nutrients is a reciprocal function of their total disappearance rate by digestion rate and passage (Allen and Mertens, 1988). Regression coefficient of RNDF on iNDF intake was 2.7-fold compared with that of pdNDF intake when either intercepts or nonintercept models were fitted, clearly indicating heterogeneity of NDF and that NDF concentration is a poor indicator of filling effects of feeds. In line with this, a bivariate model based on pdNDF and iNDF concentrations predicted DMI of grass silage better than NDF alone (Huhtanen et al., 2007) with the effect of iNDF being 3.5-fold compared with pdNDF.

When rumen iNDF and pdNDF pools were predicted from the intake of respective components, the values for intercepts were smaller than for the total NDF, but still statistically significant. This suggests that iNDF and pdNDF are more homogeneous than total NDF. By definition, iNDF behave uniformly in digestibility trials. Positive intercept in the turnover model of iNDF can be, as previously discussed, because the animals try to maintain a minimum rumen fill, and the stage of degradation of ruminal fiber under fasting probably can increase the portion of iNDF in the rumen resident mass. When the no-intercept model was fitted, the estimate of iNDF turnover time $(1.61 \mathrm{~d}=38.6 \mathrm{~h})$ is in good agreement with the values of $1.66 \mathrm{~d}$ estimated for ADL (Vieira et al., 2008) and $40.7 \mathrm{~h}$ for iNDF (Cannas et al., 2003). These values are consistent with the mean passage rate $(0.0256 / \mathrm{h})$ of iNDF derived from a data set $(\mathrm{n}=177)$ of rumen evacuation data (Krizsan et al., 2010). Data from digestibility trials in sheep fed at maintenance level demonstrated that pdNDF behaved more uniformly in the Lucas test than total NDF (Huhtanen et al., 2006). However, greater relative $\mathrm{SE}$ values of both intercept and slope for the rumen pdNDF pool compared with iNDF pool indicate that pdNDF is more heterogeneous than iNDF, probably because of the great variation in the digestion rate of pdNDF among feeds. Some studies using tropical forages reported that pdNDF could present different sub-fractions with different kinetics characteristics (Vieira et al., 2008; Souza et al., 2010). The present results support the conclusion by Cannas et al. (2003) and Vieira et al. (2008) that more detailed information of intrinsic characteristics of NDF components (e.g., iNDF, pdNDF, particle size) might produce less biased estimates of NDF turnover in the rumen. In addition to concentrations of iNDF and pdNDF, variations in the rate of pdNDF digestion and in the rate of release from 
Table 6. The best fit linear model predicting rumen NDF pool $(\mathrm{g} / \mathrm{kg}$ of BW) from fecal output and diet characteristics $(\mathrm{n}=294$; Akaike's information criterion with correction $=884$; adjusted root mean square error $=0.574)$

\begin{tabular}{llccc}
\hline Variable & Unit & Estimate & SE & $P$-value \\
\hline Intercept $^{1}$ & & 2.41 & 0.622 & $<0.001$ \\
FNDF $^{1}$ & g/kg of BW & 2.00 & 0.239 & $<0.001$ \\
FNDF $\times$ FNDF & g/kg of BW & -0.102 & 0.0250 & $<0.001$ \\
NDF & g/kg of DM & 0.0033 & 0.00090 & $<0.001$ \\
Animal $^{2}$ & 0 or 1 & -1.07 & 0.417 & 0.01 \\
F-group A $^{3}$ & Fraction 0-1 & -0.85 & 0.270 & 0.002 \\
F-group B & Fraction 0-1 & 1.00 & 0.280 & $<0.001$ \\
\hline
\end{tabular}

${ }^{1}$ Fecal NDF output $(\mathrm{g} / \mathrm{kg}$ of BW).

${ }^{2}$ Animal $=$ dummy variable: dairy cow $=0$; growing cattle $=1$.

${ }^{3}$ Proportion of corn silage + alfalfa of total forage intake on DM basis.

${ }^{4}$ Proportion of tropical grass + whole-crop silage + straw of total forage intake on DM basis.

Table 7. The best fit power function model $\left(\mathrm{RNDF}=\mathrm{A} \times \mathrm{NDFI}^{\mathrm{c}}\right)^{1}$ predicting rumen NDF pool $(\mathrm{g} / \mathrm{kg}$ of BW) from NDF intake and from animal diet characteristics $(n=210$; Akaike's information criterion with correction $=663)$

\begin{tabular}{llcrr}
\hline Variable & Unit & Estimate & SE & $P$-value \\
\hline Constant (A) & & & & \\
Intercept & & 3.42 & 0.406 & $<0.001$ \\
Animal $^{2}$ & or 1 & -0.90 & 0.219 & $<0.001$ \\
F-Group A & Fraction $0-1$ & -0.28 & 0.115 & 0.018 \\
Exponent (c) & & 0.48 & 0.052 & $<0.001$ \\
Intercept & & 0.76 & 0.109 & $<0.001$ \\
iNDF & $\mathrm{kg} / \mathrm{kg}$ of DM & -0.37 & 0.136 & 0.008 \\
$\mathrm{CP}$ & $\mathrm{kg} / \mathrm{kg}$ of DM & & & \\
\hline
\end{tabular}

${ }^{1} \mathrm{C}=0.48+0.76 \times \mathrm{iNDF}-0.37 \times \mathrm{CP}$.

${ }^{2}$ Animal $=$ dummy variable: dairy cow $=0$; growing cattle $=1$.

${ }^{3}$ Proportion of corn silage + alfalfa of total forage intake on DM basis.

${ }^{4} \mathrm{iNDF}=$ indigestible NDF.

Table 8. The best fit Mitscherlich model $\left[\mathrm{RNDF}=\mathrm{A} \times\left(1-\mathrm{e}^{c \times \mathrm{X}}\right)\right]^{1}$ predicting rumen NDF pool $(\mathrm{g} / \mathrm{kg}$ of $\mathrm{BW})$ from fecal output and diet characteristics $(\mathrm{n}=294$; Akaike's information criterion with correction $=895)$

\begin{tabular}{llccc}
\hline Variable & Unit & Estimate & SE & $P$-value \\
\hline $\begin{array}{llll}\text { Asymptote A } \\
\text { Constant }\end{array}$ & & 17.2 & 1.50 & $<0.001$ \\
Animal $^{2}$ & 0 or 1 & -1.28 & 0.740 & 0.09 \\
F-GroupA $^{3}$ & Fraction 0-1 & -1.76 & 0.489 & 0.001 \\
F-GroupB $^{4}$ & Fraction 0-1 & 1.64 & 0.490 & $<0.001$ \\
Exponent $^{c}$ & g/kg of BW & -0.175 & 0.0318 & $<0.001$ \\
FNDF $^{5}$ & Fraction 0-1 & -0.220 & 0.0323 & $<0.001$ \\
\hline
\end{tabular}

${ }^{1} \mathrm{C}=-0.175 \times$ FNDF $-0.220 \times$ NDFProp.

${ }^{2}$ Animal $=$ dummy variable: dairy cow $=0$; growing cattle $=1$.

${ }^{3}$ Proportion of corn silage + alfalfa of total forage intake on DM basis.

${ }^{4}$ Proportion of tropical grass + whole-crop silage + straw of total forage intake on DM basis.

${ }^{5} \mathrm{FNDF}=$ fecal NDF output $(\mathrm{g} / \mathrm{kg}$ of BW).

${ }^{6} \mathrm{NDFProp}=$ proportion of forage NDF of total NDF $(\mathrm{kg} / \mathrm{kg})$. 
the rumen nonescapable pool to the escapable pool can affect rumen turnover.

In addition to intrinsic feed factors, NDF digestibility is affected by extrinsic factors (Mertens, 1993), which may therefore influence RNDF. For low-quality forages, limitations in the rate and extent of digestion can be attributed to a deficiency in the supply of essential nutrients such as N, S, or in some cases branched-chain VFA (Hoover, 1986). In the present study, dietary CP concentration had a negative effect on rumen NDF pool with both linear and nonlinear models based on NDF intake. With low-quality forages, a limited supply of rumen degradable $\mathrm{N}$ can inhibit NDF digestion and passage (Detmann et al., 2009) and therefore influences RNDF at equal NDF intake. However, positive responses in diet digestibility have also been observed with high-quality dairy cow diets (Oldham, 1984; Nousiainen et al., 2009). Moreover, Cannas and Van Soest (2000) showed that forage NDF passage rate measured with external markers at equal NDF levels of intake increased as dietary CP concentration increased.

Increased proportion of concentrate in the diet at equal NDF intake ( $\mathrm{g} / \mathrm{kg}$ of BW) and dietary iNDF concentration was associated with increased rumen NDF pool (Table 5). Increased NDF pool size with highconcentrate diets can be attributed to reduced rate of pdNDF digestion with increased dietary concentrations of starch or sugars (Khalili and Huhtanen, 1991; Stensig et al., 1998; Oba and Allen, 2003; Souza et al., 2010). In a study with growing cattle fed at fixed levels of DMI, RNDF tended to increase due to reduced rate of pdNDF digestion when the proportion of concentrate increased from 50 to $75 \%$ on DM basis despite reduced NDF intake (Huhtanen and Jaakkola, 1993).

\section{Fecal Output Models}

Fecal NDF output was a better predictor of RNDF than NDF intake, especially in a univariate model that did not take into account dietary characteristics. This can be because both intrinsic characteristics of NDF (e.g., pdNDF:iNDF, rate of pdNDF digestion, and particle size), and extrinsic animal and diets characteristics (e.g., feeding level, associative effects between diet components) influence NDF digestibility (and fecal output of NDF). For example, the effect of dietary concentration of iNDF when included in models predicting RNDF from fecal NDF output was not significant. Associative effects between diet components can have a strong influence on rumen NDF pool even at equal NDF intake and characteristics. Among these observations is 14 and $17 \%$ greater fecal NDF output and RNDF when different sucrose supplements were given to cattle fed grass silage-based diets (Khalili and Huhtanen, 1991). Tesfa (1993) reported increases of 39 and $63 \%$ in fecal NDF output and rumen NDF pool in response to supplementation of a grass silage-based diet with rapeseed oil (about 7\% of DMI). On the other hand, fecal NDF seems more homogeneous compared with dietary NDF. Such statement can be supported by considering that iNDF has a more homogeneous behavior in digestibility trials, as previously discussed. After digestion, a great part of pdNDF is removed from NDF. It increases the proportion of iNDF in fecal NDF compared with dietary NDF, which in turn makes fecal NDF more homogeneous.

Significant quadratic effect of fecal NDF may be attributed to increased passage rate with increased intake. Negative effect of the proportion of concentrate

Table 9. The best fit power function model $\left(\mathrm{RNDF}=a \times \mathrm{FNDF}^{c}\right)^{1}$ predicting rumen NDF pool $(\mathrm{g} / \mathrm{kg}$ of BW) from fecal output (FNDF; $\mathrm{g} / \mathrm{kg}$ of BW) and diet characteristics ( $\mathrm{n}=294$; Akaike's information criterion with correction $=871$ )

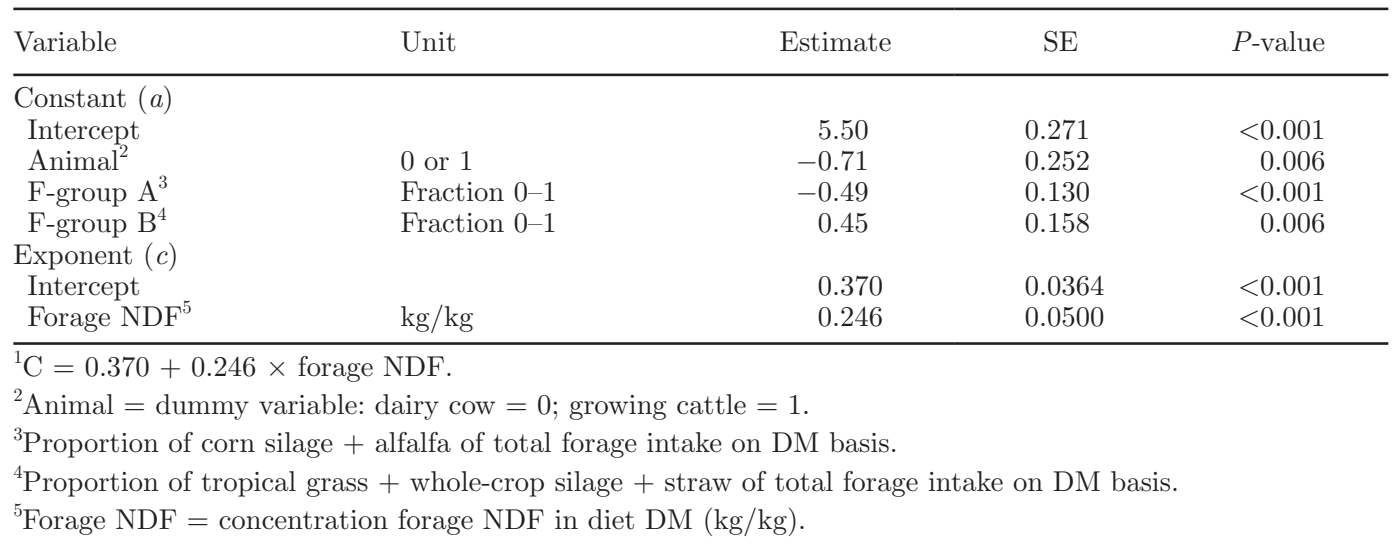


at equal fecal NDF output on rumen NDF pool is opposite to its effect on intake model. This could be related to faster turnover of concentrate NDF in the rumen (Table 3), whereas in the intake model the positive effect of concentrate proportion can be related to adverse effects of NSC on NDF digestion. The positive association of dietary concentrations total or forage NDF and RNDF pool at equal fecal NDF output is consistent with slower turnover of forage NDF compared with concentrate NDF (24 vs. 15 h with no-intercept models). The difference was smaller compared with Vieira et al. (2008), who assumed that fractional digestion and passage rates for concentrates were twice as large as the corresponding rates for forages. Mertens (1994b) developed a model in which the filling effect of a diet is represented entirely by weight of NDF of large particles, and suggested that fluid and small particles contribute little to the filling effect of the diet. Although this approach could theoretically be valid, differences in evaluation methodologies and quantitative definitions of large particle may limit its practical applications. Large variation in rumen large particle pool both within and especially between studies has been observed in dairy cows fed silage-based diets (Bosch et al., 1992; Bayat et al., 2010).

In approximately half of the studies, digestibility was determined using internal or external markers that can increase random variation in estimates of FNDF. Variation in the contribution of hind-gut to total NDF digestion can increase bias in the estimates of rumen RNDF predicted from FNDF. However, the contribution of ruminal digestion of total NDF digestion was approximately $95 \%$ in a data set from omasal sampling studies using a triple-marker method for estimating digesta flow (Huhtanen et al., 2010). This reflects partly the short residence time in postruminal fermentation compartments (Ellis et al., 2002) and lower potentially digestible mass of NDF entering the hind-gut due to digestion in the forestomachs.

\section{Effects of Animal and Forage Type}

In both linear and nonlinear models based on fecal output, rumen pool size at equal fecal NDF output was greater in dairy cows than in growing cattle. The most evident reason for this is a larger rumen volume relative to BW. In the present data rumen pool size was larger $(P<0.001)$ in dairy cows than in growing cattle both on fresh weight (139 vs. $120 \mathrm{~g} / \mathrm{kg}$ of BW) and DM basis (18.1 vs. $13.9 \mathrm{~g} / \mathrm{kg}$ of BW). Because of greater rumen capacity in dairy cows it is possible that at equal intake or fecal output of NDF rumen residence time was longer in dairy cows. Illius and Gordon (1992) reported that the turnover time in the rumen scales to $\mathrm{BW}^{0.25}$.
Significant effects of forage type demonstrated that chemical and morphological differences between forage types may influence the rate of breakdown of particles (Wilson and Kennedy, 1996). Differences in fragility of forage particles affect rate of particle size breakdown and retention time in the reticulo-rumen (McLeod and Minson, 1988). In the study of Kammes and Allen (2012), an alfalfa diet increased the rate of particle size reduction of iNDF from large to small compared with an orchardgrass diet (7.16 vs. $4.67 \% / \mathrm{h})$ and passage rate of small iNDF particles (3.85 vs. $2.66 \% / \mathrm{h})$. Similarly, rumen retention time of iNDF was approximately $10 \mathrm{~h}$ shorter with corn silage-based diets compared with grass silage-based diets (Lund, 2002; Krämer et al., 2013). Menezes et al. (2011) verified that sugarcane diets presented lower degradation $(1.2$ vs. $2.6 \% / \mathrm{h})$ and passage $(2.6$ vs. $3.5 \% / \mathrm{h})$ rates of NDF when compared with corn silage diets. In that study, the RNDF was $54 \%$ greater for animals fed sugarcane, reflecting the slower ruminal turnover of sugarcane NDF.

Oliveira et al. (2011) performed a meta-analysis on the effect of dietary NDF on intake in lactating cows in tropical conditions. These authors found that increased concentrate NDF did not influence the DMI when corn silage was used, but increased DMI when sugarcane was supplied to the animals. Moreover, these authors found that forage NDF from sugarcane depressed DMI 3.5-fold more that forage NDF from corn silage. These results reinforce the different effects of forage and nonforage NDF on rumen pool and again show the heterogeneity of NDF from different feed sources.

In a meta-analysis of rumen evacuation data (Krizsan et al., 2010), passage rate of iNDF was faster for diets based on mixtures of corn and alfalfa silages compared with diets based on grass silage at equal NDF intake. Negative effects of diets based on corn and alfalfa silages on RNDF are therefore likely be related to the faster rates of breakdown of large particles to small particles and passage rate of small particles from the rumen. The association between fecal NDF output and rumen pool size is positive when fecal NDF output increases due to reduced digestion rate or increased iNDF concentration, whereas with increased passage at equal digestion rate and iNDF concentration the relationship is negative.

\section{Nonlinear Models}

Statistically the differences between linear and nonlinear models predicting RNDF from fecal output were rather small. The major deviations between the models occurred at very low $(\leq 1.0 \mathrm{~g} / \mathrm{kg}$ of BW $)$ and very high $(\geq 8.0 \mathrm{~g} / \mathrm{kg}$ of $\mathrm{BW})$ fecal NDF output. However, only 8 from 294 observations were outside of this range. 
However, biased estimates of rumen NDF pool for diets associated with low fecal NDF output should not be a problem because the intake of these diets is not limited by rumen fill. Quadratic models are often inadequate when used to predict over a range of data outside of those used to develop the relationship and can be unsuitable for extrapolation. Maximum rumen NDF pool $(13.4 \mathrm{~g} / \mathrm{kg}$ of BW) was predicted at fecal NDF output of $9.4 \mathrm{~g} / \mathrm{kg}$ of BW followed by a decline. In spite of providing useful information to understand the physical and biological influences of different animal and diet variables, the linear models do not seem more accurate to predict rumen pool size. Therefore, to avoid any pitfalls of linear and quadratic models as mentioned previously, using nonlinear models is preferred. Among the nonlinear models, the power function model was slightly better in terms of AICC and residual variance than the Mitscherlich model. Further, because the power function model has no maximum value, it may have a wider ability than the Mitscherlich model to account better for those observations at extreme values of fecal NDF output.

\section{CONCLUSIONS}

Due to the intrinsic heterogeneous nature of NDF in dairy cow diets, RNDF could not be predicted accurately from NDF intake alone. Predictions were improved when dietary variables reflecting differences in digestion and passage characteristics of NDF were included in the model. Models based on fecal NDF output performed better than models based on NDF intake. At equal NDF intakes, increased dietary iNDF concentration is associated with greater RNDF, and at equal fecal NDF output rumen NDF pool size was positively related to concentration of forage NDF in the diet. Nonlinear models can avoid the pitfalls of linear and quadratic models when applied over wider ranges of data. It is concluded that developed models can result in an improved evaluation of the filling effect of the diet, better understanding of the additive nature of physical and physiological mechanisms affecting feed intake, and more accurate predictions of voluntary feed intake.

\section{ACKNOWLEDGMENTS}

The authors thank Torsten Eriksson and Rolf Spörndly from the Swedish University of Agricultural Sciences (Uppsala, Sweden), and Egil Prestløkken and Harald Volden from the Norwegian University of Life Sciences (Ås, Norway) for providing unpublished data for this study, and Anne-Katrine Skovsted Schulze from the University of Copenhagen (Copenhagen, Denmark) for providing additional data.

\section{REFERENCES}

Allen, M. S. 1996. Physical constraints on voluntary intake of forages by ruminants. J. Anim. Sci. 74:3063-3075.

Allen, M. S., and D. R. Mertens. 1988. Evaluating constraints on fiber digestion by rumen microbes. J. Nutr. 118:261-270.

Bayat, A. R., M. Rinne, K. Kuoppala, S. Ahvenjärvi, A. Vanhatalo, and P. Huhtanen. 2010. Ruminal large and small particle kinetics in dairy cows fed red clover and grass silages harvested at two stages of growth. Anim. Feed Sci. Technol. 155:86-98.

Belsley, D. A., E. Kuh, and R. E. Welsch. 1980. Regression Diagnostics: Identifying Influential Data and Sources of Collinearity. John Wiley \& Sons, New York, NY.

Blaxter, K. L., F. W. Wainman, and R. S. Wilson. 1961. The regulation of food intake by sheep. Anim. Prod. 3:51-61.

Bosch, M. W., S. C. W. Lammers-Wienhoven, G. A. Bangma, H. Boer, and P. W. M. Van Adrichem. 1992. Influence of stage of maturity of grass silages on digestion processes in dairy cows. 2. Rumen contents, passage rates, distribution of rumen and faecal particles and mastication activity. Livest. Prod. Sci. 32:265-281.

Cannas, A., and P. J. Van Soest. 2000. Simple allometric models to predict rumen feed passage rate in domestic ruminants. Pages 49-62 in Modelling Nutrient Utilization in Farm Animals. J. P. McNamara, J. France, and D. E. Beever, ed. CAB International, Wallingford, UK.

Cannas, A., P. J. Van Soest, and A. N. Pell. 2003. Use of animal and dietary information to predict rumen turnover. Anim. Feed Sci. Technol. 106:95-117.

Colucci, P. E., G. K. MacLeod, W. L. Grovum, I. McMillan, and D. J. Barney. 1990. Digesta kinetics in sheep and cattle fed diets with different forage to concentrate ratios at high and low intakes. J. Dairy Sci. 73:2143-2156.

Conrad, H. R., A. D. Pratt, and J. W. Hibbs. 1964. Regulation of feed intake in dairy cows. I. Change in importance of physical and physiological factors with increasing digestibility. J. Dairy Sci. 47:54-62.

Crampton, E. W. 1957. Interrelations between digestible nutrient and energy content, voluntary dry matter intake, and the overall feeding value of forages. J. Anim. Sci. 16:546-552.

Detmann, E., M. P. Gionbelli, and P. Huhtanen. 2014. A meta-analytical evaluation of the regulation of voluntary intake in cattle fed tropical forage-based diets. J. Anim. Sci. 92:4632-4641.

Detmann, E., M. F. Paulino, H. C. Mantovani, S. C. Valadares Filho, C. B. Sampaio, M. A. Souza, I. Lazzarini, and K. S. C. Detmann. 2009. Parameterization of ruminal fibre degradation in low-quality tropical forage using Michaelis-Menten kinetics. Livest. Sci. 126:136-146.

Ellis, W. C., M. J. Wylie, and J. H. Matis. 2002. Validity of specifically applied rare earth elements and compartmental models for estimating flux of undigested plant tissue residues through the gastrointestinal tract of ruminants. J. Anim. Sci. 80:2753-2758.

Fisher, D. S., J. C. Burns, and K. R. Pond. 1987. Modelling ad libitum dry matter intake by ruminants as regulated by distension and chemostatic feedbacks. J. Theor. Biol. 126:407-418.

Hoover, W. H. 1986. Chemical factors involved in ruminal fiber digestion. J. Dairy Sci. 69:2755-2766.

Huhtanen, P., and S. Jaakkola. 1993. The effects of forage preservation method and proportion of concentrate on digestion of cell wall carbohydrates and rumen digesta pool size in cattle. Grass Forage Sci. 48:155-165.

Huhtanen, P., J. Nousiainen, and M. Rinne. 2006. Recent developments in forage evaluation with special reference to practical applications. Agric. Food Sci. 3:293-323.

Huhtanen, P., M. Rinne, and J. Nousiainen. 2008. Evaluation of the concentrate factors affecting silage intake of dairy cows; a development of the relative total diet intake index. Animal 2:942-953. 
Huhtanen, P., M. Rinne, and J. Nousiainen. 2007. Evaluation of the factors affecting silage intake of dairy cows: A revision of the relative silage dry matter intake index. Animal 1:758-770.

Huhtanen, P., S. Ahvenjärvi, G. A. Broderick, S. M. Reynal, and K. J. Shingfield. 2010. Quantifying ruminal digestion of organic matter and neutral detergent fiber using the omasal sampling technique in cattle-A meta-analysis. J. Dairy Sci. 93:3203-3215.

Illius, A. W., and I. J. Gordon. 1992. Modelling the nutritional ecology of ungulate herbivores: Evolution of body size and competitive interactions. Oecologia 89:428-434.

Kammes, K. L., and M. S. Allen. 2012. Rates of particle size reduction and passage are faster for legume compared with cool-season grass, resulting in lower rumen fill and less effective fiber. J. Dairy Sci. 95:3288-3297.

Keady, T. V. J., C. S. Mayne, N. W. Offer, and C. Thomas. 2004. Prediction of voluntary intake. Pages 1-7 in Feed into Milk. C. Thomas, ed. Nottingham University Press, Nottingham, UK.

Khalili, H., and P. Huhtanen. 1991. Sucrose supplements in cattle given grass silage based diet. 2. Digestion of cell wall carbohydrates. Anim. Feed Sci. Technol. 33:262-273.

Krämer, M., P. Lund, and M. R. Weisbjerg. 2013. Rumen passage kinetics of forage- and concentrate-derived fiber in dairy cows. J. Dairy Sci. 96:3163-3176.

Krizsan, S. J., S. Ahvenjärvi, and P. Huhtanen. 2010. A meta-analysis of passage rate estimated by rumen evacuation with cattle and evaluation of passage rate prediction models. J. Dairy Sci. 93:5890-5901.

Littell, R. C., G. A. Milliken, W. W. Stroup, and R. D. Wolfinger. 1996. SAS ${ }^{\circledR}$ system for mixed models. SAS Institute Inc., Cary, NC.

Lund, P. 2002. The effect of forage type on passage kinetics and digestibility of fibre in dairy cows. PhD Thesis. The Royal Veterinary and Agricultural University, Copenhagen, Denmark.

Mambrini, M., and J. L. Peyraud. 1997. Retention time of feed particles and liquids in the stomach of ruminants and intestines of dairy cows. Direct measurements and calculations based on faecal collection. Reprod. Nutr. Dev. 37:427-442.

McLeod, M. N., and D. J. Minson. 1988. Large particle breakdown by cattle eating ryegrass and alfalfa. J. Anim. Sci. 66:992-999.

Menezes, G. C. C., S. C. Valadares Filho, F. A. Magalhães, R. F. D. Valadares, L. D. Mariz, E. Detmann, O. G. Pereira, and M. I. Leão. 2011. Total and partial digestibility, rates of digestion obtained with rumen evacuation and microbial protein synthesis in bovines fed fresh or ensiled sugar cane and corn silage. Rev. Bras. Zootec. 40:1104-1113.

Mertens, D. R. 1987. Predicting intake and digestibility using mathematical models of ruminal function. J. Anim. Sci. 64:1548-1558.

Mertens, D. R. 1993. Kinetics of cell wall digestion and passage in ruminants. Pages 535-570 in Forage Cell Wall Structure and Digestibility. H. G. Jung, D. R. Buxton, R. D. Hatfield, and J. Ralph, ed. American Society of Agronomy, Madison, WI.

Mertens, D. R. 1994a. Regulation of forage intake. Pages 450-493 in Forage Quality, Evaluation and Utilization. G. C. Fahey Jr., ed. American Society of Agronomy Inc., Crop Science Society of America Inc., Soil Science Society of America Inc., Madison, WI.

Mertens, D. R. 1994b. Using a mass action model of ruminal function to estimate the filling effect of forage NDF. Page 27 in Proc. IVth Intl. Workshop on Modelling Nutrient Utilization in Farm Animals. Natl. Inst. Anim. Sci., Foulum, Denmark.
Nousiainen, J., M. Rinne, and P. Huhtanen. 2009. A meta-analysis of feed digestion in dairy cows. 1. The effects of forage and concentrate factors on total diet digestibility. J. Dairy Sci. 92:5019-5030.

Oba, M., and M. S. Allen. 2003. Effects of corn grain conservation method on ruminal digestion kinetics for lactating dairy cows at two dietary starch concentrations. J. Dairy Sci. 86:184-194.

Oldham, J. D. 1984. Protein-energy interrelationships in dairy cows. J. Dairy Sci. 67:1090-1114

Oliveira, A. S., E. Detmann, J. M. S. Campos, D. S. Pina, S. M. Souza, and M. G. Costa. 2011. Meta-analysis of the impact of neutral detergent fiber on intake, digestibility and performance of lactating dairy cows. Rev. Bras. Zootec. 40:1587-1595.

Poppi, D. P., B. W. Norton, D. J. Minson, and R. E. Hendricksen. 1980. The validity of the critical size theory for particle leaving the rumen. J. Agric. Sci. Camb. 94:275-280.

Rinne, M., P. Huhtanen, and S. Jaakkola. 2002. Digestive process of dairy cows fed silages harvested at four stages of grass maturity. J. Anim. Sci. 80:1986-1998.

Souza, M. A., E. Detmann, M. F. Paulino, C. B. Sampaio, I. Lazzarini, and S. C. Valadares Filho. 2010. Intake, digestibility and rumen dynamics of neutral detergent fiber in cattle fed low-quality tropical forage and supplemented with nitrogen and/or starch. Trop. Anim. Health Prod. 42:1299-1310.

St-Pierre, N. R. 2001. Integrating quantitative findings from multiple studies using mixed model methodology. J. Dairy Sci. 84:741-755.

Stensig, T., M. R. Weisbjerg, and T. Hvelplund. 1998. Digestion and passage kinetics in dairy cows as affected by the proportion of wheat starch or sucrose in the diet. Acta Agric. Scand. A. Anim. Sci. 48:129-140.

Tesfa, A. T. 1993. Effects of rape-seed oil supplementation on digestion, microbial protein synthesis and duodenal microbial amino acid composition in ruminants. Anim. Feed Sci. Technol. 41:313328

Van Soest, P. J. 1994. Nutritional Ecology of the Ruminant. Cornell Univ. Press, Ithaca, NY.

Van Soest, P. J., J. France, and R. C. Siddons. 1992. On the steadystate turnover of compartments in the gastrointestinal tract. J. Theor. Biol. 159:135-145.

Vieira, R. A., L. O. Tedeschi, and A. Cannas. 2008. A generalized compartmental model to estimate the fibre mass in the reticulorumen: 2. Integrating digestion and passage. J. Theor. Biol. 255:357-368.

Vieira, R. A. M., P. R. S. S. Campos, J. F. Coelho da Silva, L. O. Tedeschi, and W. P. Tamy. 2012. Heterogeneity of the digestible insoluble fiber of selected forages in situ. Anim. Feed Sci. Technol. 171:154-166.

Wilson, J. R., and P. M. Kennedy. 1996. Plant and animal constraints to voluntary feed intake associated with fibre characteristics and particle breakdown and passage in ruminants. Aust. J. Agric. Res. $47: 199-225$.

Wylie, M. J., W. C. Ellis, J. H. Matis, E. M. Bailey, W. D. James, and D. E. Beever. 2000. The flow of forage particles and solutes through segments of the digestive tract of cattle. Br. J. Nutr. 83:295-306.

Yan, T. F., J. Gordon, C. P. Ferris, R. E. Agnew, M. G. Porter, and D. C. Patterson. 1997. The fasting heat production and effect of lactation on energy utilisation by dairy cows offered forage-based diets. Livest. Prod. Sci. 52:177-186. 